УДК 793.31.077(477.84)"195/198"

DOI: $10.31866 / 2616-7646.3 .2 .2020 .220533$

\title{
ОСОБЛИВОСТІ ФУНКЦІОНУВАННЯ ТАНЦЮВАЛЬНОЇ ХУДОЖНЬОЇ САМОДІЯЛЬНОСТІ В ТЕРНОПІЛЬСЬКІЙ ОБЛАСТІ РАДЯНСЬКОГО ПЕРІОДУ
}

\author{
Підлипський Андрій Ігорович, \\ викладач, \\ Київський національний університет культури і мистецтв, \\ Київ, Україна, \\ https://orcid.org/0000-0001-8086-3532, \\ pidlipaukr.net
}

\begin{abstract}
Мета статті - виявити особливості функціонування і політико-ідеологічний контекст танцювальної художньої самодіяльності в Тернопільській області радянської доби. Методологія. Об'єктивність дослідження забезпечило використання аналітичного (аналіз літератури та джерел, зокрема архівних документів, фактів), історичного (викладення матеріалу в хронологічній послідовності), культурологічного (розгляд подій крізь призму соціокультурної ситуації) підходів. Наукова новизна. Уперше акцентовано увагу на політико-ідеологічному контексті розвитку художньої самодіяльності в Тернопільській області; уведено до наукового обігу нові архівні матеріали. Висновки. У 50-80-х pp. XX ст. в Тернопільській області, подібно до інших територій СРСР, було створено розгалужену мережу аматорських танцювальних колективів, що можна розцінювати не тільки як прояв морального піднесення після звільнення від фашистів, а і як латентну форму боротьби за збереження національно-культурної ідентичності. Відсутність до 1961 р. професійного ансамблю народного танцю в регіоні дало змогу стабілізувати репертуар самодіяльним колективам у тісному зв'язку з фольклором, не орієнтуючись на досягнення професійного мистецтва. Історико-політична специфіка тернопільського регіону проявилась у підвищеній увазі під час організування зарубіжних гастролей до учасників танцювальних колективів, чиї родичі були пов’язані з еміграцією із західноукраїнських земель, а також з Організацією Українських Націоналістів. Основними факторами, що зумовлювали діяльність колективів художньої самодіяльності, були не лише творчі, а й політико-ідеологічні, визначені системою тоталітарного суспільства з командно-адміністративним управлінням.
\end{abstract}

Ключові слова: танцювальна художня самодіяльність; Тернопільська область; народна хореографія; ансамбль народного танцю; танець. 


\section{ОСОБЕННОСТИ ФУНКЦИОНИРОВАНИЯ ТАНЦЕВАЛЬНОЙ ХУДОЖЕСТВЕННОЙ САМОДЕЯТЕЛЬНОСТИ В ТЕРНОПОЛЬСКОЙ ОБЛАСТИ СОВЕТСКОГО ПЕРИОДА}

\author{
Пидлыпский Андрей Игоревич, \\ преподаватель, \\ Киевский национальный университет \\ культуры и искусств, \\ Киев, Украина, \\ https://orcid.org/0000-0001-8086-3532, \\ pidlipQuukr.net
}

Цель статьи - выявить особенности функционирования и политико-идеологический контекст танцевальной художественной самодеятельности в Тернопольской области советской эпохи. Методология. Объективность исследования обеспечило использование аналитического (анализ литературы и источников, в том числе архивных документов, фактов), исторического (изложение материала в хронологической последовательности), культурологического (рассмотрение событий сквозь призму социокультурной ситуации) подходов. Научная новизна. Впервые акцентировано внимание на политикоидеологическом контексте развития художественной самодеятельности в Тернопольской области; введено в научный оборот новые архивные материалы. Выводы. В 50-80-х гг. ХХ в. в Тернопольской области, подобно к другим территориям СССР, была создана разветвленная сеть любительских танцевальных коллективов, что можно расценивать не только как проявление морального подъема после освобождения от фашистов, но и как латентную форму борьбы за сохранение национально-культурной идентичности. Отсутствие до 1961 г. профессионального ансамбля народного танца в регионе позволило стабилизировать репертуар самодеятельным коллективам в тесной связи с фольклором, не ориентируясь на достижения профессионального

\section{PECULIARITIES \\ OF DANCE AMATEUR ACTIVITIES FUNCTIONING IN THE TERNOPIL REGION OF THE SOVIET PERIOD}

\author{
Andrii Pidlypskyi, \\ Kyiv National University \\ of Culture and Arts, \\ Lecturer, \\ Kyiv, Ukraine, \\ https://orcid.org/0000-0001-8086-3532, \\ pidlipQukr.net
}

The purpose of the article is to identify the peculiarities of the functioning and the political and ideological context of dance amateur performances in the Ternopil region of the Soviet period. Methodology. The objectivity of the study was ensured by the use of analytical (analysis of literature and sources, including archival documents, facts), historical (presentation of material in chronological sequence), culturological (consideration of events through the prism of the socio-cultural situation) approaches. Scientific novelty. For the first time, attention is focused on the political and ideological context of the amateur performances' development in the Ternopil region; new archival materials were introduced into scientific circulation. Conclusions. In the 50-80s of the twentieth century in the Ternopil region, as well as throughout the USSR, an extensive network of amateur dance groups was created, which can be regarded not only as a manifestation of moral upsurge after liberation from the Nazis but as a latent form of struggle to preserve national and cultural identity. The absence of a professional folk dance ensemble in the region until 1961 made it possible to stabilize the repertoire of amateur groups in close connection with folklore, without focusing on the achievements of professional art. The historical and political specificity of the Ternopil region manifested itself in the increased attention during the organization of foreign tours to the participants of dance groups, 
искусства. Историко-политическая специфика тернопольского региона проявилась в повышенном внимании при организации зарубежных гастролей к участникам танцевальных коллективов, чьи родственники были связаны с эмиграцией из западноукраинских земель, а также с Организацией Украинских Националистов. Основными факторами, которые обусловили деятельность коллективов художественной самодеятельности, были не только творческие, но и политико-идеологические, определенные системой тоталитарного общества с командно-административным управлением.

Ключевые слова: танцевальная художественная самодеятельность; Тернопольская область; народная хореография; ансамбль народного танца; танец. whose relatives were associated with waves of emigration from Western Ukrainian lands, as well as with the Organization of Ukrainian $\mathrm{Na}-$ tionalists. The main factors that determined the activities of amateur art groups were not only creative but also political and ideological as a sign of the system of a totalitarian society with command and control.

Keywords: dance amateur performances; Ternopil region; folk choreography; folk dance ensemble; dance.

Актуальність теми дослідження. Важливим аспектом дослідження хореографічної культури України радянського періоду є виявлення регіональної специфіки розвитку художньої самодіяльності. Незважаючи на загальні для Радянського Союзу принципи підтримки колективів танцювальної художньої самодіяльності, які були покликані популяризувати позитивний характер радянського устрою, демонструвати в узаконених формах єдність народів СРСР, можна виявити особливості, пов'язані не тільки з національною і регіональною специфікою танцювального мистецтва, а й із певними історико-політичними подіями в західноукраїнському регіоні, зокрема в Тернопільській області.

Аналіз останніх досліджень та публікацій. Проблеми функціонування самодіяльних колективів народного танцю в Україні порушували Л. Андрощук (2018), Т. Луговенко (2018), К. Островська (2010) та ін. До регіональних особливостей розвитку танцювальної художньої самодіяльності «радянської» Тернопільщини звертаалися А. Підлипський (2018), Л. Щур (2020). Однак у жодній праці не було акцентовано увагу на політико-ідеологічному контексті функціонування танцювальної художньої самодіяльності в Тернопільській області цього часу.

Мета статті - виявити особливості функціонування і політико-ідеологічний контекст танцювальної художньої самодіяльності в Тернопільській області радянського періоду.

Виклад основного матеріалу. 3 огляду на той факт, що територія Тернопільської області була приєднана до Радянського Союзу в 1939 р. перед німецько-радянської війною (у радянській історіографії - Велика Вітчизняна війна 1941-1945 рр.), організовані радянські форми самодіяльності не були вкорінені до війни; мережа танцювальних колективів художньої самодіяльності за радянським зразком створювалася фактично вперше. Відповідно до завдань соціалістичного й культурного будівництва, створювалася система підпорядкування дер- 
жаві аматорського мистецтва, котра розумілася як «організована художня самодіяльність».

Періодом масового виникнення колективів художньої самодіяльності в Тернопільській області стали 50-80-ті pp. ХХ ст. Незважаючи на те, що ці роки в СРСР в цілому також вважаються розквітом танцювальної художньої самодіяльності, можна вести мову про певну регіональну специфіку, оскільки відбувалося не післявоєнне відродження, як на переважній території Радянського Союзу, а створення нової системи «художньої самодіяльності».

Ситуація післявоєнного патріотичного підйому на території СРСР по завершенні Другої світової війни пов'язана зі звільненням від німецької окупації та 3 почуттями гордості народу-переможця, його сподіваннями на мирне щасливе життя, відбудову зруйнованого господарства. На західноукраїнських територіях цей підйом пояснюється ще й непереборним бажанням зберегти ознаки національного. У такій ситуації створення аматорських танцювальних осередків народного танцю в узаконених радянською владою формах (колективи «художньої самодіяльності») можна розцінювати як латентну боротьбу за національно-культурну незалежність, збереження національної ідентичності. Як констатує Т. Луговенко (2018), «попри ідеологічне втручання з боку державних та партійних органів, у радянські роки в середовищі художньої самодіяльності кристалізувалися підходи до втілення засобами народно-сценічного танцю фольклорних першоджерел» (с. 388), що, на наш погляд, стало позитивним не лише в аспекті еволюціонування сценічних танцювальних форм, пов’язаних 3 народною культурою, а й одним із можливих шляхів збереження етнокультурних кодів у дозволений спосіб.

Також важливе значення у становленні системи колективів художньої самодіяльності в Тернопільській області відіграв факт відсутності в регіоні до 1961 р. професійного ансамблю народно-сценічного танцю. Це певним чином дало змогу стабілізувати репертуар самодіяльним колективам у тісному зв'язку з фольклором, не орієнтуючись на вимоги професійного мистецтва. Надмірне бажання досягти рівня професійного виконавства, як засвідчив досвід багатьох регіонів СРСР, призвело до вихолощення фольклорної компоненти сценічних постановок, віддалення від народних танців, перенасичення репертуару самодіяльних колективів номерами, не пов'язаними з конкретними першоджерелами, які $є$ плодом балетмейстерської фантазії, своєрідними стилізаціями, що були не народними, а лише гранично схожими на народні.

Переважна частина професійних ансамблів народного танцю, ансамблів пісні і танцю, танцювальних груп при народних хорах в СРСР створювалася з колишніх учасників художньої самодіяльності. Саме в такий спосіб при Тернопільській державній філармонії було сформовано перший професійний ансамбль танцю «Надзбручанка». Зі спогадів керівника відділу культосвітньої роботи у Мельнице-Подільській, згодом директора Тернопільського міського будинку культури, обласного будинку народної творчості, театру ляльок, першого заступника начальника обласного управління культури Юліана Кройтора (2008) дізнаємося, що у «Будинку народної творчості проводили курси підготовки артистів для майбутнього ансамблю народного танцю. Керував ними досвідчений балетмейстер-постановник В. Дяконов із м. Львова. Уперше було підготовлено програму, що складалася з двох відділів. Нараховувалося 14 пар танцюристів, їхні виступи відбува- 
лись під супровід оркестру... Навчання танцюристів закінчилося на початку 1961 року. Колектив із 45 осіб віддали міському будинку культури. Управління культури виділило дві вантажні криті автомашини, щоб виїжджати на гастролі. Колектив назвали “Надзбручанкою". 3 цього часу почалась історія цього чудового самобутнього ансамблю танцю... У липні 1961 року “Надзбручанку” перевели в обласну філармонію. Це був уже професійний мистецький колектив» (с. 18).

Зарубіжні поїздки професійних і самодіяльних танцювальних колективів в Радянському Союзі мали характер своєрідної культурної дипломатії, покликаної пропагувати переваги радянського способу життя. Всі учасники колективів проходили ретельну перевірку на благонадійність і відданість країні. Показовим щодо історико-політичної специфіки тернопільського регіону є документ, який демонструє посилену увагу до учасників танцювального колективу, чиї родичі були пов’язані з різними хвилями еміграції із західноукраїнських земель, а також з діяльністю Організації Українських Націоналістів. Перед закордонною поїздкою одного з танцювальних колективів художньої самодіяльності (ансамбль пісні і танцю «Дністер», який був створений у 1969 р. працівниками Заліщицького районного будинку культури Теодором Хмуричем і Мар’яном Романюком (Luteza, 2015) до ЦК Компартії України з Комітету держбезпеки при раді Міністрів Української РСР було передано «Спеціальне повідомлення», датоване 4 липня 1974 р. й позначене грифом «Таємно» (відмітка «нетаємно» поставлена лише 27 червня 2013 р.). Також на документі поставлена позначка «Тов. Щербицькому В. В. повідомлено» (В. Щербицький у цей час - перший секретар ЦК Компартії Української РСР).

Зазначений архівний документ свідчить: «На початку серпня 1974 року до Франції для участі у фестивалі етнографічних колективів виїжджає ансамбль пісні і танцю «Дністер» Заліщицького будинку культури Тернопільської області у складі 34 осіб.

На родичів ряду учасників цього ансамблю є компроментуючі матеріали. Зокрема, батько методиста ансамблю Шатківського А. Т. був станичним ОУН, в 1950 році осуджений за націоналістичну діяльність до 10 років ВТТ (виправно-трудових таборів - А. П.). Мати та сестра Шатківського листуються з родичами, що мешкають у США та Канаді. Дядя художнього керівника ансамблю Кравчука 3. $Є$. як учасник банди ОУН був засуджений до 15 років позбавлення волі. Кравчук 3. Є. та його мати підтримують переписку з родичами у США.

Батько керівника сільського самодіяльного народного хору Хмурича Т. М., члена КПРС, у 1941 році був засуджений до 10 років ВТТ за участь у націоналістичній організації, що готувала збройний виступ проти радянської влади.

Батько учасника ансамблю Лисака Я. В. у 1951 році був засуджений до 15 років ВТТ за Указом Президії Верховної Ради СРСР від 4 червня 1947 року за розкрадання соціалістичного майна.

Керівник гуртка художньої самодіяльності Кузьма І. С. та його мати листуються з родичами, що мешкають в США та Аргентині.

Учасники ансамблю: Лопух В. С., Слободян В. В. та Сорока Є. А., члени ВЛКСМ, мають родичів в капіталістичних країнах та підтримують з ними письмовий зв’язок.

Всі перераховані особи характеризуються позитивно, беруть активну участь у суспільному житті, даних про їх ворожі наміри у зв’язку з майбутньою поїздкою за кордон не отримано. 
Доповідається в порядку інформування» (Комитет государственной безопасности Украинской ССР, 1974). Підписано документ головою Комітету держбезпеки при Раді Міністрів Української РСР В. Федорчуком.

У зв'язку з цим варто зазначити, що «Спеціальне повідомлення» з'явилося після того, як у 1973 р. ансамбль виступав на Всесоюзному фестивалі народної творчості, присвяченому 50-річчю створення СРСР. За успішні виступи в програмі фестивалю керівники колективу Зіновій Кравчук і Мар'ян Романюк були нагороджені Золотою медаллю (Luteza, 2015, 2:31), а всі учасники ансамблю - нагрудним знаком ВДНГ СРСР «Учаснику творчого показу».

Незважаючи на «Спеціальне повідомлення», ансамбль пісні і танцю «Дністер» у серпні 1974 р. успішно гастролював по Франції (фольклорний фестиваль у м. Олерон, 17-й фольклорний фестиваль пісні і танцю в м. Конфолан) та Англії (10-й міжнародний фольклорний фестиваль у м. Біллінгем). Балетмейстер ансамблю Мар'ян Романюк, хормейстер - Зіновій Кравчук, керівник оркестру Орест Шатківський. Усі учасники ансамблю, чиї прізвища були вказані в «Спеціальному повідомленні», гастролювали з колективом. До складу адміністративної групи входив майор КДБ, що було обов’язковим для поїздок творчих колективів за кордон в часи СРСР.

Отже, діяльність колективів художньої самодіяльності регламентувалася не тільки творчими, а й політико-ідеологічними аспектами, що пояснюється умовами тоталітарного режиму із системою командно-адміністративного управління.

Наукова новизна. Уперше акцентовано увагу на політико-ідеологічному контексті розвитку художньої самодіяльності в Тернопільській області; уведено до наукового обігу нові архівні матеріали.

Висновки. У 50-80-х pp. XX ст. в Тернопільській області, подібно до інших територій СРСР, було створено розгалужену мережу аматорських танцювальних колективів, що можна розцінювати не лише як прояв морального піднесення після звільнення від фашистів, а і як латентну форму боротьби за збереження національно-культурної ідентичності. Відсутність у в регіоні до 1961 р. професійного ансамблю народного танцю дало змогу самодіяльним колективам стабілізувати репертуар у тісному зв'язку з фольклором, не орієнтуючись на досягнення професійного мистецтва. Історико-політична специфіка тернопільського регіону проявилась у підвищеній увазі під час організування зарубіжних гастролей до учасників танцювальних колективів, чиї родичі були пов’язані з еміграцією із західноукраїнських земель, а також з Організацією Українських Націоналістів. Основними факторами, що зумовлювали діяльність колективів художньої самодіяльності, були не лише творчі, а й політико-ідеологічні, визначені системою тоталітарного суспільства 3 командно-адміністративним управлінням.

\section{СПИСОК БІБЛІОГРАФІЧНИХ ПОСИЛАНЬ}

Андрощук, Л. М. (2018). Діяльність аматорського колективу в системі хореографічнопедагогічної освіти в Україні. Актуальні питання мистецької освіти та виховання, 2(12), 197-205. 
Комитет государственной безопасности Украинской ССР. (1974, 4 июля). Специальное сообщение (Ф. 16. Оп. 01. Д. 1093. Л. 200-201). Галузевий державний архів Служби безпеки України, Київ.

Кройтор, Ю. Г. (2008). Понад півстоліття у культурі Тернопілля. Тернограф.

Луговенко, Т. (2018). Специфіка розвитку аматорських хореографічних колективів народного танцю у 40-80 pp. ХХ ст. Молодий вчений, 7(59), 385-388.

Островська, К. В. (2010). Народна хореографія України II половини XX століття та її професійний розвиток. Вісник Харківської державної академії дизайну і мистецтв, 1, 226228.

Підлипський, А. (2018). Аматорські колективи народно-сценічного танцю Тернопільщини другої половини XX - початку XXI століття. Культура і сучасність, 1, 187-193.

Щур, Л. (2020). Структурно-функціональні аспекти хореографічної культури Західного Поділля. Молодь і ринок, 1(180) 165-170. https://doi.org/10.24919/2308-4634.2020.196217.

Luteza. (2015, 20 сентября). Народний ансамбль пісні і танцзю «Дністер». Фотохроніка 19691981 [Відео]. YouTube. https://www.youtube.com/watch?v=xCzJSt7vs9c\&feature=emb_ logo.

\section{REFERENCES}

Androshchuk, L. M. (2018). Diialnist amatorskoho kolektyvu v systemi khoreohrafichnopedahohichnoi osvity v Ukraini [The Activity of an Amator Group in the System of Horeographic-Pedagogical Education in Ukraine]. Current Issues of Art Education, 2(12), 197-205 [in Ukrainian].

Committee for State Security of the Ukrainian SSR. (1974, July 4). Spetsial'noe soobshchenie [Special Message] (F. 16. Op. 01. D. 1093. L. 200-201). The SSU Sectoral State Archive, Kyiv [in Russian].

Kroitor, Yu. H. (2008). Ponad pivstolittia u kulturi Ternopillia [More Than Half a Century in the Culture of Ternopil Region]. Ternohraf [in Ukrainian].

Luhovenko, T. (2018). Spetsyfika rozvytku amatorskykh khoreohrafichnykh kolektyviv narodnoho tantsiu u 40-80 rr. XX st. [Development Specifics of Amateur Folk Dance Groups in the 40-80's of the 20th Century]. Young Scientist, 7(59), 385-388 [in Ukrainian].

Luteza. (2015, September 20). Narodnyi ansambl pisni i tantsiu "Dnister". Fotokhronika 1969-1981 [Folk Song and Dance Ensemble "Dniester". Photochronicle 1969-1981] [Video]. YouTube. https://www.youtube.com/watch?v=xCzJSt7vs9c \&feature=emb_logo [in Ukrainian].

Ostrovska, K. V. (2010). Narodna khoreohrafiia Ukrainy II polovyny XX stolittia ta yii profesiinyi rozvytok [Folk Choreography of Ukraine in the Second Half of XX Century and It's Professional Development]. Bulletin of Kharkiv State Academy of Design and Arts, 1, 226228 [in Ukrainian].

Pidlypskyi, A. (2018). Amatorski kolektyvy narodno-stsenichnoho tantsiu Ternopilshchyny druhoi polovyny XX - pochatku XXI stolittia [Amateur Groups of Folk-Stage Dance of Ternopil Region the Second Half of XX - the Beginning of the XXI Century]. Culture and Contemporaneity, 1, 187-193 [in Ukrainian].

Shchur, L. (2020). Strukturno-funktsionalni aspekty khoreohrafichnoi kultury Zakhidnoho Podillia [Structural and Functional Aspects of Choreographic Culture of Western Podillya]. Youth \& Market, 1(180) 165-170 [in Ukrainian]. 